\title{
Judicial Censure and Moral Communication to Youth Sex Offenders
}

\author{
Kathleen Daly and Brigitte Bouhours \\ Griffith University
}

\begin{abstract}
Professor Kathleen Daly
Brisbane, Queensland 4111

AUSTRALIA

Office $\quad+61(0) 73735-5625$

fax $\quad(0) 73735-5608$

home $\quad(0) 7$ 3216-1630
\end{abstract}

School of Criminology and Criminal Justice

Griffith University, Mt Gravatt Campus

email: k.daly@griffith.edu.au

Ms Brigitte Bouhours

School of Criminology and Criminal Justice

Griffith University, Mt Gravatt Campus

Brisbane, Queensland 4111

AUSTRALIA

Office $\quad+61(0) 73735-5951$

fax $\quad(0) 73735-5608$

home $\quad(0) 73342-2934$

email: b.bouhours@griffith.edu.au

Paper under review, 23 July 2007

Acknowledgments

This project was funded by two Australian Research Council grants. We thank the South Australia Court Administration Authority and the Youth Court for their cooperation, and the (then) Senior Youth Court Judge, Andrea Simpson, who was instrumental in initiating the project. We would also like to thank Sarah Curtis Fawley. 


\title{
Judicial Censure and Moral Communication to Youth Sex Offenders
}

\author{
Abstract \\ The philosophical underpinnings of youth courts rest on the notion that youths are less \\ culpable and more reformable than adults. Ideally, when sentencing youth crime, some \\ scholars argue that judges should engage youthful offenders in moral communication to \\ elicit change. But do they? What more generally do judges say to the youths? This \\ paper analyzes the frequency and content of judicial censure and moral communication \\ in the sentencing of youth sex offenders. Drawing on the sentencing remarks for 55 \\ sexual violence cases, we examine the ways in which judges interact with youths and \\ censure the offenses, and what, if any, normative guidance they give concerning gender, \\ sexuality, and violence. We found that in most, but not all cases, the judges censured \\ the offending as both a moral and legal wrong. However, they spent more time \\ discussing a youth's future than past behavior, as they sought to elicit change. The \\ judges did not degrade or exclude the offenders; rather, they addressed them in a spirit \\ of reintegration, as worthy individuals with future potential. Although the judges set \\ norms of appropriate sexual behavior to the youths when the offense victims were \\ children, they did not always do so when victims were female peers. In this Youth \\ Court, "real rape" was sexual offending by a youth against a child under 12 years of \\ age. By contrast, in about one-fifth of cases, all of which occurred against a female \\ peer, the offending was censured only as a legal wrong (a "pseudo censure”) and less \\ likely subject to judicial norm setting.
}




\section{Introduction}

Research on youth sentencing has focused largely on the severity or types of sanctions imposed, but less attention has been given to the equally important matter of what is said to youths in the courtroom on the day of sentencing. For example, what moral messages do judges attempt to convey during a sentence hearing, and how do judges interact with youthful defendants? Tait (2002) argues, and we agree, that much can be learned by analyzing sentencing as a "violence-invoking performance, the official ritual of denunciation or forgiveness” (p. 470). For youth courts, empirical research shows that such denunciations are softened to reflect youths’ reduced culpability (e.g., Travers, 2007). Such practices accord with normative claims that youths should be viewed as less culpable and that sentencers of youth crime should engage in moral communication (Duff, 2002; Weijers, 2002, 2004).

This article contributes to the empirical literatures on youth court practices and court responses to sexual violence, and to the normative literature on sentencing as moral communication. We present and analyze the sentencing remarks in 55 cases of the legally most serious forms of youthful sexual offending, which were sentenced in the South Australian Youth Court from 1995 to mid-2001, with these questions in mind: What do judges say to the young people in court? What is the character of their moral communication? What, if any, normative guidance do judges give to youth, especially with respect to appropriate gender relations and sexuality?

In a companion piece (Bouhours \& Daly, 2007), we examine the ways in which the judges characterized the sexual offenses and offenders, and how they justified their sentences. This paper examines the ways in which judges censure youth sex offending, including the normative messages they attempt to convey to the youths, and how, more 
generally, they interact and communicate with them. We explore proposals by Weijers (2002) and Warner (2002) that judicial officers should engage youth in a moral dialogue, which, in cases of sexual offending, challenges sexual aggression. Finally, we examine the likely impact of the judicial communication on offenders and victims.

\section{COURTROOM COMMUNICATION AND INTERACTIONS}

Ours is the first empirical study of courtroom interactions in the sentencing process for youth sex offenders. In reviewing the literature on judicial ${ }^{1}$ interactions in adult or youth courts, two strands are relevant to our study: first, a normative strand, what judges ought to say in the courtroom; and second, an empirical strand, what they do say. After reviewing this literature, we consider the relevance and meaning of sentencing remarks as “data.”

\section{What judges ought to say to offenders}

Scholars propose a variety of recommendations for what judges ought to say to youthful offenders to advance their moral education, provoke remorse, and challenge their beliefs.

Censure

Von Hirsch (1993) describes censure as the expression of an adverse judgment toward someone whose conduct is reprehensible, with the accompanying sentiment of disapproval. He suggests that a penal sanction on its own, or threats of further legal liabilities, may bring compliance, but do not address an offender's moral agency. Thus, it is essential that a moral message, which expresses censure and disapproval of the

\footnotetext{
${ }^{1}$ We use the term judges and judicial through out this paper to refer generally to judicial officers in criminal courts, which includes magistrates in some countries.
} 
behavior, accompanies a sanction. Censure conveys to offenders (and others) that the act committed was wrong, and it offers redress to victims by recognizing that their suffering was caused by someone else.

Von Hirsch (1993) takes a retributive approach to sentencing in that he views its primary purpose as backward-looking (to censure an offense), not forward-looking (to change an offender or an offender's attitude). Although he acknowledges that censure may lead to an expression of remorse or contrition by wrongdoers, he sees this as a collateral benefit. Like von Hirsch, Duff (2002) is a retributivist; however, he views the censuring process as having a consequentialist potential for moral education, and especially when youth are sentenced. He suggests that sentencers can take a more proactive role in relating punishment (as a "secular penance,” p. 130) to a wrongdoer's selfreform. For youth, he suggests that "we must try to bring them to face up to and recognize the wrongs they have done ..., to see the need for apologetic reparation, ... and to embark (with our help) on the necessary task of self-reform” (Duff, 2002: 132). Beyond censure: a pedagogical perspective Weijers' (2002, 2004) arguments are based on what he sees as effective forms of communication in the youth court, both at trial and sentencing. His "pedagogical perspective on juvenile justice” is a more fully consequentialist approach that imagines an even more pro-active role for judges in moral education. ${ }^{2}$ He argues that judges should actively engage in a moral dialogue with offenders, as if they were parents or teachers, to help youths understand the negative consequences of their behavior. Such a dialogue could "function ... as a moral reference point in the life of the young offender" (2002: 145). Weijers (2004: 27) warns, however, that the moral education of youth

\footnotetext{
${ }^{2}$ Weijers initially developed his arguments in the context of an inquisitorial system, and thus, he discusses the role of his pedagogical perspective in the judicial fact-finding process as well as in sentencing.
} 
should not take the form of a "paternalistic reprimand" that focuses on what the youth “has done wrong, their moral and social ‘failing,' and an expectation [that they will change].” Rather the moral communication should focus on the harm caused, and it should ask critical questions that offenders may have previously overlooked or refused to consider. In doing so, judges should attempt to appeal to a youth's "sense of morality, empathy [for the victim], guilt and remorse” (p. 26), and stimulate an offender's self-reflection with the aim of eliciting change.

Sexual aggression and violence: challenging beliefs

For offenses of sexual aggression and violence, some feminist scholars argue that the court's message should attempt to challenge extant attitudes and beliefs that support male sexual aggression, i.e., the moral communication should include a normative framework about appropriate gender relations and sexuality (Friedman, 1998; Warner, 2002, 2005). According to Murnen et al.'s (2002) meta-analysis of studies exploring the link between masculine ideology and sexual aggression, adherence to traditional gender roles that condone men's dominance of and sexual aggression toward women is widespread. The study also shows that adolescent males' support for traditional gender roles and sexuality is learned early and reinforced by male peers. In addition, surveys indicate that a significant proportion of high school and university students (both male and female) hold unfavorable attitudes toward rape victims and accept stereotypical rape myths (e.g., for Australia, Xenos \& Smith, 2001; Friedman, 1998; for the UK, Epps, Haworth, \& Swaffer, 1993; for the US, Anderson, Simpson-Taylor, \& Herrman, 2004; White \& Kurpius, 1999).

Warner (2002, 2005) proposes that judges should use the sentencing hearing as a forum to challenge male sexual aggression toward females. Specifically, she says that 
“sentencing remarks ... could be used to challenge the dominant cultural assumptions and perspectives on sexuality and to infuse modern ideas about normal sexuality and sex roles into the law” (2005: 248). For example, judges could confront widespread myths such as women enjoy being forced into sex or a woman owes a man sex if she accepts that he pays for a meal on a date (Friedman, 1998). Hudson (2002: 631) is less sanguine that offenders would even hear or absorb such communication because they are likely to focus on the penalty, although this could change if greater emphasis were placed on "discursive processes" at sentencing. It is important to note here that Warner and Hudson have in mind sexual violence involving adult male offenders and female victims, when, as we shall see in the youth court, a substantial share of youth (almost all of whom are male) sexually offend against children, both male and female.

\section{Degradation vs. reintegration}

All commentators agree that the aim of judicial communication should not be to degrade offenders or undermine their self-esteem, as famously depicted in Garfinkel's (1956) “degradation ceremonies.” Weijers (2002) and Taylor (2002) concur with von Hirsch (1993) that humiliating and demeaning treatment of wrongdoers (whether adult or youth) does not encourage a positive moral response. Rather, the moral dialogue should endeavor to stimulate young offenders to distance themselves from and condemn the offense, along the lines of Braithwaite's (1989) notion of reintegrative shaming, elaborated by Braithwaite and Mugford (1994), who said that restorative justice conferences were able to accomplish this better than regular court processes. In line with Hudson’s (2002) point above about the discursive potential in sentencing, Weijers (2002) argues that a dialogic approach in judge-youth interactions could extend some benefits of conferences to the courtroom. 


\section{What judges say to the offenders}

\section{Moral communication}

Studies show that when sentencing adults or youth, judges attempt to communicate to offenders that their actions were wrong, especially when a harsh penalty is not imposed. For example, Mileski (1971) found that when judges imposed relatively lenient penalties on adult defendants, they balanced such leniency with "situational sanctions" by lecturing and reprimanding offenders for their behavior. In an analysis of sentencing remarks in men's and women's felony cases, Daly (1994) explored Mileski’s finding further. She found that it applied more to the men: judges were more likely to lecture male defendants when they imposed non-jail sentences, but they lectured to most of the women, whether they were jailed or not. Further, the judges spoke more positively about women's reform potential. These findings for women in the adult court hold more generally for all adolescents in the youth court. Recent studies suggest that judges view youth as reformable and have not given up attempting to deter them. For example, in his study of the sentencing of youths transferred to a New York City adult court, Kupchik (2003, 2004; see also Kupchik, 2006) observed that, rather than imposing detention, judges intended to "help defendants by admonishing them.” Similarly in a New South Wales youth court, Vignaendra and Hazlitt (2005: 63) found that judges typically reprimanded the youths, but that the posture of judicial communication was "benevolent paternalism” with "advice and boundary setting."

Studies of sexual assault show that censure is more likely to occur when cases involve adult offenders and child victims than when offenders and victims are both adult. In an analysis of trial judgments and sentencing decisions in Canadian sexual 
assault cases, ${ }^{3}$ Coates and colleagues $(1994,2004)$ found that legal officers failed to condemn the assault as a violent and coercive event, and often transformed it into a mutual sexual encounter. By contrast, in their analysis of child sexual assault cases in Canada, MacMartin and Wood (2005) found that when adults had sexually offended against children, judges strongly censured the behavior by denouncing the offender's exploitation of vulnerable victims.

Interactions in the youth court

Youth courts are typically less formal and legalistic than adult courts, but because of their inexperience, youth may be more intimidated by the court process. From his observations of a US juvenile court in the 1960s, Emerson (1969) suggested that youth court judges, bearing this potential for intimidation in mind, conducted the sentencing hearing with the aim of deterring youth from further offending. He depicted the “courtroom ceremony” as “degrading and humiliating” (p. 213), saying that judges gave moralistic lectures in which they tended to accentuate the youths' responsibility, discredit their moral character, and threaten them with further sanctions if the offending continued. Australian youths, who were interviewed following their sentencing in the Queensland Children’s Court in the 1980s, reported that they were intimidated by the court process, which they did not understand. They felt ignored, powerless, and belittled, and described their experience as being “ 'talked about' and 'talked at', talked down to and threatened” (O’Connor \& Sweetapple, 1988: 71).

Reprimands and admonishments, reminiscent of Mileski’s (1971) situational sanctions, together with threats of further legal liabilities, if a youth re-offends, are seen in recent research on youth courts, although compared to the literature of the 1960s to

\footnotetext{
${ }^{3}$ The age of victims in the sample is not stated; it may have included child victims, but the authors' analysis and discussion assume adult victims.
} 
1980s, judicial officers are described as more polite and somewhat caring (e.g., Kupchik, 2004; Tait, 2002; Travers, 2007; Vignaendra \& Hazlitt, 2005). Even though Kupchik (2003) likens the judge’s address to a degradation, he points out that the aim was not to put down offenders, but to encourage them to change their behavior.

Kupchik (2003, 2004) observed some instances of youth-judge dialogue, when the judge endeavored to find out about an offender's past and current circumstances. By contrast, much of the literature across the decades, describes youth court interactions as one-way discourses by the judges or other court officials. For example, in his analysis of one youth court case, Tait (2002: 475) depicted the sentencing performance as "a solo performance” by the judicial officer: the youth was expected to listen to a “negative evaluation of his behavior” and to receive "some free advice,” but he was not asked to speak, think, or explain himself. In comparing juvenile courts in England and Holland, Weijers (2004) argues that adversarial court procedures in common law countries thwart any exchanges between judge and youth, but inquisitorial procedures can encourage a dialogue between the judge and youth.

Because ours is the first study of youth court processes in handling sex offending, it is uncertain how judges will interact with these youths. In light of the gravity of the sex offenses, many of them against children, might judges adopt a harsher stance than is typical in youth courts? We explore this and other questions raised by the literature: How do judges censure these offenses? Do they engage in forms of moral communication that go beyond paternalistic reprimands or solo performances? Do they seek to exclude or reintegrate offenders? 


\section{Sentencing remarks as “data”}

Like the authors reviewed above, we assume that judges’ sentencing remarks are important and consequential speech acts, even if, it would appear, there are no studies of their effects on defendants or wider audiences. (Note that prepared and recorded remarks are typically available only in more serious cases that are sentenced in higher courts, variously named District or felony courts, rather than in summary or magistrates’ courts, where about 90\% of cases are sentenced.) Formal sentencing remarks are important because they constitute an official record (albeit selected and partial) of the ways in which the state legitimates and justifies its power to punish. ${ }^{4}$ In analyzing them, we learn how judicial officials relate general sentencing principles to individual cases. We also learn how a judge, as the authorized spokesperson for the state in censuring and sanctioning crime, speaks to a defendant and, at times, a larger audience about what is right and wrong social conduct. In youth courts, which are often closed to members of the general public, a judge typically cannot use the occasion to "send signals to others that crime will not go unpunished" (that is, general deterrence) as may occur in adult courts. ${ }^{5}$ However, the remarks can reveal official judgments of the character of the offender and offense, along with varied forms of advice-giving, norm setting, or norm clarification (Christie, 1977). Like other speech acts, sentencing remarks can be analyzed as "real” and as "socially constructed." We are interested in how the manifest and latent content of the remarks can reveal socially constructed notions of "more" and "less serious" forms of youth sexual offending, and what implies

\footnotetext{
${ }^{4}$ It does not matter if this official record is routine and desultory, or dramatic and meaningful. Its importance lies in its official status as a state record. Analyses of the remarks can then evaluate their varied meanings and potential impact.

${ }^{5}$ In fact, in the jurisdiction we studied, the relevant sentencing act was amended in 1996, which made it impermissible for a judicial officer to take general deterrence into account when sentencing youth offenders in youth court.
} 
for the court's norm clarification. We are also interested in how judges communicate with youths, and how they resolve a justice problem of sanctioning serious crime committed by those, who because of their age, may be viewed as less culpable. ${ }^{6}$

\section{METHODS}

This study of judicial sentencing is part of a larger project, which analyzed all youth sex offense cases finalized by police formal caution, family conference, or in the Youth Court during a 6 1⁄2 year period (1995 to 2001) in South Australia, and whose broad aim is to examine the appropriateness of restorative justice in cases of youth sexual and family violence (Daly, 2006; Daly et al., 2007; Daly \& Curtis-Fawley, 2006). During the $6 \frac{1}{2} 2$ period, there were a total of 65 cases sentenced by judges; our analysis is of 55 cases for which sentencing remarks could be located. ${ }^{7}$ Further detail on the study’s context and methods is given elsewhere (Bouhours \& Daly, 2007; Daly et al., 2007).

\section{Sample features}

Of the 55 cases, the proved offense that was legally most serious was rape or attempted rape (18\%), unlawful sexual intercourse with a victim under 12 (27\%), unlawful sexual

\footnotetext{
${ }^{6}$ Some suggest that the arguments and pronouncements by the key legal actors in sentencing (i.e., the prosecutor, defense attorney, and judge) are "a bit of charade" because the sentence has already been decided by them in advance (Heumann, 1977: 45). However, sentencing remarks do more in that they are supposed to communicate censure and justify a sanction. They may include many other elements that are tailored to an individual defendant.

${ }^{7}$ A total of 226 youth cases that began with one or more sex offense charges were finalized in the Youth Court during the $6 \frac{1}{2}$ year research period: 115 were proved of a sexual offense (almost all by guilty plea), 8 were proved of non-sexual offenses, 100 were dismissed or withdrawn, and three were acquitted. Of the 115 cases of proved sex offending, 50 were sentenced by magistrates (who sentence the less serious cases and whose sentencing remarks are not routinely transcribed); and 65, by judges, who sentence the more serious cases. For the ten missing remarks, the South Australian Youth Court staff conducted an extensive search in the judges' files and court archives to locate them; but despite their efforts, they could not be found. A comparison of the ten cases without remarks and the 55 with remarks, revealed no major differences; however, as defined in the results section, the missing cases had a somewhat higher share of Category 2 cases and a lower share of Category 1 cases.
} 
intercourse with a victim aged 12 to 16 (24\%), indecent assault (25\%), incest (2\%), and indecent behavior (4\%). ${ }^{8}$ In 12 cases, non-sexual offenses were sentenced at the same time as the sexual offense; and in some instances, judges considered a robbery to be more serious than a sexual offense, such as unlawful sexual intercourse with a victim aged 12 to 16 . On average, the cases took $4 \frac{1}{2}$ months from the first to the final hearing, although a few cases took over one year before they were sentenced. Just two cases were convicted at trial, with almost all youths having entered a guilty plea.

All offenders, except one, were male; but most victims (78\%) were female. This court has jurisdiction over offenses committed by those from 10 years of age to under 18. The offender's mean age at the time of sentencing was 16.6. ${ }^{9}$ About a third had an official history of previous offending, including sexual offending in three cases. In over half the cases, judges mentioned the youths had problems, including having been abused while growing up (physically, sexually, or emotionally), having a mental or intellectual impairment, abusing alcohol or drugs, suffering from mental health problems, or having a troubled family background.

The victims' mean age at the time of the offense was 11.5 years. Half were under 12, and three were over 18 . Twelve cases had male victims, a high share (83\%) of whom were under 12 years. By comparison, less than half (42\%) of the 43 female victims were under 12 . The offenses with under-12 victims were more likely to be

\footnotetext{
${ }^{8}$ There is a significant degree of charge and sentence reduction in the Youth Court: $64 \%$ of the 55 cases were charged with rape at police arrest.

${ }^{9}$ This excludes one offender who was sentenced when he was 27 for an offense he committed as a youth. The mean age of the youth at the time of the offense was 15.7 years. We take care in reporting the findings to distinguish the age of the offender at the time of offending and at the time of sentence. When the age of victims is reported, it is when the offense(s) occurred.
} 
intra-familial than extra-familial. ${ }^{10}$ Almost all the victims knew the offender in some way, either as a family member, a friend, a neighbor, or an acquaintance; only two involved strangers. Five cases had Indigenous youthful offenders, but the racial classification of victims was rarely given.

The most common sentence outcome was an order to "be of good behavior" (86\%), ${ }^{11}$ and it was often joined with supervision by a Families and Youth Services worker (67\%). Next in frequency was referral to Mary Street, which is a therapeutic program that specializes in the treatment and prevention of adolescent sexual offending (58\%). ${ }^{12}$ Youths were also referred to education or job training programs (22\%) or to other forms of therapy such as drug or alcohol abuse programs (15\%). Some were ordered to perform community service (15\%); few were fined (6\%). Detention was imposed in 33\% of cases, but was suspended for all but two cases. In three cases, no penalty was imposed at all.

\section{Sentencing remarks}

The sentencing remarks are a verbatim transcript of the judge's homily at the sentence hearing. They vary in length, ranging from just over 100 words to nearly 3,000 words, with an average of about 1,000 words. In the remarks, judges typically discuss the offense and its effects on the victim(s) and families, as well as on the offender. They then outline and justify the factors they consider relevant, citing aggravating or

\footnotetext{
${ }^{10}$ Intra-familial offenses involved siblings, cousins, and step or foster relations, as well as two babysitters. Extra-familial offenses involved friends, casual acquaintances, neighbors, and those not known to the victim.

${ }^{11}$ This means that the youth is potentially subject to further sanctions, if there is re-offending.

${ }^{12}$ Mary Street is an outpatient facility where young people attend regular appointments with their therapists, normally for a year (see Daly et al., 2007: 85).
} 
mitigating circumstances, before announcing the sentence. The remarks are longer when victims are under 12 and shortest when the judges assume the offense is consensual underage sex between those of a similar age. The remarks were delivered by five different judges, who used somewhat different linguistic styles and rhetoric. ${ }^{13}$

The content of the remarks was analyzed using a combination of deductive and inductive approaches (Berg, 2004: 272-73). The coding was not limited to the manifest content of the text (the words used by the judges), but extended to the latent content (the meaning conveyed by the message). A detailed coding schedule was designed to read, interpret, and code the remarks in a systematic manner; and it was expanded and refined after many readings of the remarks. To understand the prosecution and sentencing of youth in this jurisdiction, we also interviewed key legal officers and clinical or social welfare workers in Adelaide, South Australia. Among those interviewed were two judges, who sentenced over half the cases in the sample.

We highlight several points about the context and impact of the sentencing remarks. The remarks form only part of the sentence hearing, and as such, they are a partial and selected record. On the day of sentencing, a prosecutor will first summarize the offense and justify or discuss a penalty in light of other cases and the offender's criminal history. Then the defense attorney will speak, outlining mitigating factors or other redeeming qualities of the defendant, especially efforts to change since the offense occurred. Then, the judge will give the sentence homily. Except for a defense attorney’s advice to a youth to listen to the judge, or the judge's saying to a youth, “please listen to me,” there is no further effort to prepare the youth for what the judge might say. In their remarks, the judges may refer to things that have been said by others

\footnotetext{
${ }^{13}$ We do not analyze linguistic styles and rhetoric, including variation by gender, to preserve the judges’ anonymity. All the judges were white and non-Indigenous.
} 
(for example, what a defense attorney notes from a pre-sentence report); and for that reason, they say, they do not repeat this information. Nor do they necessarily repeat offense details, although they may quote verbatim from documents such as a victim impact statement.

If, as we have said, sentencing remarks are important speech acts, several questions arise: to whom are the remarks directed, what are the judge's aims, and does a youth understand what the judge is saying? We know that at a minimum the key legal actors and the defendant are present in the courtroom, but with some exceptions, the remarks do not indicate systematically who else is there. Those who are likely to be present include the defendant's parent(s), guardian(s), or caseworker. (In none of the sentencing remarks was it evident that a victim was present or permitted to speak in the courtroom.) Although in all cases, the remarks were directed to the youth, the judge occasionally had a larger audience in mind. In five cases the judges used the remarks to reinforce social norms against the sexual abuse of children to both the youth and a wider audience. In one case, for example, the judge expressed concern "that the community not see these offenses as in some way minimized by the Court” because of the penalty imposed.

The two judges we interviewed said that their main aim in addressing the youth was to stop them from further offending. We do not know if a youth "heard" or understood what the judge was saying in this or any other court. Systematic research is lacking, but the sparse evidence suggests that during a sentence hearing, youths focus mainly on what the penalty will be: they may be too nervous (Hudson, 2002) or intimidated by the 
process (O’Connor \& Sweetapple, 1988) to fully comprehend or absorb what is being said. $^{14}$

\section{RESULTS}

\section{Three categories of cases and offenders}

The court interactions and moral communication can only be understood with reference to the study's overall major finding, which is that the 55 cases fell into three discrete categories. In each category, the judges’ sentencing discourse reflected a different set of ideas about the cases. ${ }^{15}$ Despite somewhat different linguistic styles, the five judges had a consistent orientation to these cases.

Category 1 contains 32 cases, which included all the cases with victims under 12 and all the cases where victims and offenders were siblings; in these cases, 34\% of victims were male. Half the cases in Category 1 were intra-familial: in ten, the victims and offenders were biological or stepsiblings; and in six, they were cousins. The youths in Category 1 were viewed by the judges as posing a potential threat as sexual offenders in the making, and all were referred to the Mary Street program for the prevention of adolescent sex offending. Judges depicted the sexual behavior as aberrant (that is, not acceptable and not normal), when they reflected upon the victim’s young age and relationship to the offender. The victims in Category 1 were never described as having consented to the sexual interaction.

\footnotetext{
${ }^{14}$ A psychologist from the Mary Street program told us that based on what some clients have said during therapeutic sessions, youths were more likely to understand the penalty in the conference than the court process.

15 The three-way typology is presented in greater detail in Bouhours and Daly (2007). Like all typologies, this one had some cases that did not easily fit into the categories. But on balance, it captured the variation in the cases with a high degree of accuracy.
} 
Category 2 has 13 cases and included a variety of sexual and non-sexual offenses. For two-thirds, the most serious sentenced offense was sexual. For one-third, a nonsexual offense (such as robbery) was also sentenced, and it was viewed as more serious than the sexual offense, which in some cases, was consensual sex between minors. Over half the youths in Category 2 had a serious prior criminal history, and many abused alcohol or drugs. Thus, the sexual offense was considered in the context of a criminogenic lifestyle, which caused concern to the judges. No youth in this category was referred to the Mary Street program, but one-third were referred to some kind of program, generally for substance abuse or mental health. The victims in these cases were older (on average, 15 years old) than those in Category $1 .{ }^{16}$ All were friends or acquaintances of the offender, except one victim who was the youth's cousin. The victim's lack of consent was central to the three cases in which the youth was convicted and sentenced for rape. However, even when a youth in Category 2 was convicted of unlawful sexual intercourse with a person aged 12 to 16 years, the judges suggested in court that the offenders had coerced the victims and exploited their vulnerability. ${ }^{17}$

The ten youths in Category 3 were viewed as adolescent experimenters, who were likely to mature out of their offending, and whose offending was perceived as least serious of the three groups. All the victims were female, aged 12 or over (average age

\footnotetext{
${ }^{16}$ Whereas the age gap at the time of the offense between offender and victim for Category 1 cases was 8 years, it was 3.5 years and 3 years respectively, for Categories 2 and 3.

${ }^{17}$ A rape conviction means the victim's lack of consent has been demonstrated. It carries a life sentence for adult offenders (whose penalty structure is used in this Youth Court). A conviction for unlawful sexual intercourse (USI), 12-16 years, means (legally) that an offender had consensual sexual intercourse with a victim who was older than 12 but under the legal age of consent (17 years in South Australia). It carries a penalty of 7 years' imprisonment. However, pleas to USI are permitted in cases of coerced sex, when prosecutors believe the case will not succeed at trial.
} 
was 13.6 years), who were friends or acquaintances of the offenders. ${ }^{18}$ In most cases, the sentenced offense was unlawful sexual intercourse, which the judges characterized as adolescent experimentation and underage sex between consenting peers, giving no hint that the victims were coerced. Yet, in eight cases, the victim initially reported to the police that she had been raped; thus the judge's version did not correspond to the victim's experience. There was no expressed concern with alarming or aberrant sexual behavior, or entrenched criminality, and the judges did not think a therapeutic or punitive intervention was required. The three cases that had no penalty imposed were all in Category 3. ${ }^{19}$

\section{What did judges tell offenders?}

In $91 \%$ of cases, judges censured the offense as a moral wrong, as a legal wrong, or as both. They also tried to provide moral advice to guide the youths' future behavior and future relationships. What they said varied by the three-way typology.

Censure for the offense as a moral or legal wrong

When judges censured offenses as a moral wrong, they focused on the offender's violation of the victim, by stressing a victim's physical, emotional, and psychological suffering as a result of the youth's actions; and the impact of the offense on the offender's and victim's family. When judges censured offenses as a legal wrong only, they did not mention the victim, but said that the offense represented a breach of legal norms. Of the 55 cases, $69 \%$ were censured as a moral wrong or as both a moral and a

\footnotetext{
${ }^{18}$ In four of the ten cases, the relationship was described as boyfriend/girlfriend (current or previous). All but one case involved sexual intercourse; and in all but one case, the offense took place in the offender's or victim's house or car, with no witnesses were present. In two cases, the offense occurred after a party, and the victims said they were drunk.

${ }^{19}$ Although the number of Indigenous cases is too small to analyze the relationship of racial classification to sentencing, we note that three youths were in Category 1, and two, in Category 2.
} 
legal wrong. A further $22 \%$ of offenses were censured as a legal wrong only. In five cases (9\%), there was no explicit censure. As Table 1 shows, the type of censure varies by the three-way typology. Most offenses in Categories 1 (97\%) and 2 (54\%) were censured as a moral wrong or as both moral and legal wrongs, whereas all offenses in Category 3 were censured as a legal wrong only. ${ }^{20}$ We term this a "pseudo censure” because it lacks the depth of disapproval for the offending behavior itself, as this is understood by von Hirsch and others. ${ }^{21}$

In the following Category 1 case, the judge censured the offender on moral grounds, by highlighting the harm caused to the victim:

Eventually [the victim] said that he would not put up with it anymore. [He] used the term "torturing," an indication of the pain he felt from the physical process of you inserting your penis in his anus. ... I wonder what the people who are looking after the victim would say about his progress. Very frequently in this Court, we read reports or hear evidence that the victims of abuse, when they are children, have to wear the trauma for the rest of their lives. It affects their lives. They find it difficult to trust people. They find it difficult to enter into normal friendly relationships with people because of that.

\footnotetext{
${ }^{20}$ With censure, like other elements in the remarks, more was said to the youths in Categories 1 and 2. The average number of words was 1,173 (Category 1), 949 (Category 2), and 534 (Category 3).

${ }^{21}$ For the two Category 2 cases that were censured only as legal wrongs, although the judges did not explicitly mention the wrong against the victim, they treated the cases as serious offending.
} 
Table 1. Ways in which judges censured the offense*

\begin{tabular}{|c|c|c|c|c|}
\hline Type of censure* & $\begin{array}{c}\text { Category } 1 \\
\mathrm{~N}=32 \text { cases } \\
\% \quad(\mathrm{~N})\end{array}$ & $\begin{array}{c}\text { Category } 2 \\
\mathrm{~N}=13 \text { cases } \\
\% \quad(\mathrm{~N})\end{array}$ & $\begin{array}{c}\text { Category } 3 \\
\begin{array}{c}\mathrm{N}=10 \text { cases } \\
\% \quad(\mathrm{~N})\end{array}\end{array}$ & $\begin{array}{c}\text { Total } \\
\mathrm{N}=55 \text { cases } \\
\% \quad(\mathrm{~N})\end{array}$ \\
\hline Moral wrong only* & $94 \% \quad(30)$ & $31 \%$ & none & $62 \%$ \\
\hline Moral and legal wrong & $3 \% \quad(1)$ & $23 \%$ & none & $7 \%$ \\
\hline $\begin{array}{l}\text { Legal wrong only } \\
\text { ("pseudo censure") }\end{array}$ & none & $15 \%$ & $100 \%$ & $22 \%$ \\
\hline Total cases censured & $97 \%$ & $69 \% \quad(9)$ & $100 \%$ & $91 \%$ \\
\hline
\end{tabular}

*Table notes:

1. Judges drew upon Victim Impact Statements to emphasize the moral wrong of the offense in eight Category 1 cases and one Category 2 case.

2. One Category 1 case was treated as a "lost cause" case by the judge; the youth had previous offending, and other offenses were sentenced on the same day. Despite the lack of censure, the case was treated seriously by the judge.

3. Two Category 2 cases, although censured as a legal wrong only, were treated seriously by the judge.

4. One Category 3 case was censured as a moral wrong, but the judge said the victim shared some culpability because she and her friends had been bullying the offender; thus, the case was coded as a "pseudo censure."

In the nine cases that had Victim Impact Statements (VIS), the judged censured the offense as a moral wrong. ${ }^{22}$ At times, to emphasize the harm to the victim, the judge would quote from the VIS:

[The victim] says, “I couldn’t look at Alex ${ }^{23}$ and felt sick in the tummy.” He says, “I do not want to see Alex until I am big, and I don’t want him to be my brother any more. He did a very bad thing to me and shouldn’t be near any other little kids.

\section{(Category 1)}

\footnotetext{
${ }^{22}$ All cases with a VIS, except one, were in Category 1.

${ }^{23}$ Pseudonyms are used.
} 
Although the violation of victims as a moral wrong was central to the judicial address in Category 1 and 2 cases, the judges also talked about moral wrongs in more general terms, as this exchange with Trevor (Category 1) exemplifies:

Judge: Yes. You realize, of course, that what you did to your sister was very wrong, don't you?

Trevor: Yes, but at the time I didn’t know what, like court and Magill, ${ }^{24}$ I didn’t know much about that.

Judge: Yes, but you do know now. ... You must have realized that being violent... Trevor [interrupting]: I wasn’t 100\% sure that it was wrong.

Judge: It has to be wrong to force other people to have sex. You can’t get much wronger than that, can you?

By contrast, in none of the Category 3 cases did the judges censure the offense as a violation of the victim. Instead, they depicted victims as willing participants in a sexual encounter and constructed the wrong as a breach of the law. They did this by stating that the offense was serious or by emphasizing the legal age of consent, as in this Category 3 case: "It is an offense and a serious offense to have intercourse with an underage girl.” Judges did not depict these offenses as moral wrongs, but accepted a youth's ignorance of the law as an explanation for the sexual offense, as in the case of Kurt (Category 3), who was proved of unlawful sexual intercourse with a person 12 to 16 years of age:

I think the important thing, Kurt, is that you have learnt a lesson out of all of this. ... You say - and I accept - that you didn’t know that before, but you must have known. Most young people know that there is an age of consent. I don't want to

\footnotetext{
${ }^{24}$ Magill is the main youth detention center in Adelaide.
} 
give you a lecture today Kurt. The law exists, of course, primarily to deal with those situations where, as there often is, exploitation by an older person of a younger person, but I don't see on the basis of what has been put to me that that was what happened here.

Several times judges pointed out that the law proscribing sexual intercourse with 12 to 16 year olds was directed to prohibiting adults from having sex with young people, but was not directly relevant to sexual intercourse with adolescents of similar age. They said this despite the fact that in eight of the ten Category 3 cases, the youths were initially charged with rape.

\section{No censure cases}

In five cases, there was no explicit expression of judicial censure (four cases were in Category 2, and one, in Category 1). In two, the judges treated the offenders as "lost causes” (Emerson, 1969): the youth appeared unable to help themselves and had lengthy criminal histories. ${ }^{25}$ (In one, the youth was sentenced to serve detention time.) In two others, the youths demonstrated that they were remorseful for what they had done and had kept out of trouble since the offense; the judges may have thought that an expression of censure was not required. In the fifth case, which was sentenced for sexual and non-sexual offenses, the judge focused on the youth's need to address his mental health and drug use problems. The youth’s future welfare received more judicial attention than the offending itself.

\section{Norm-setting}

In two-thirds of cases overall, the judges provided norms of behavior to the youths in their future actions. Their injunctions were to respect others, to protect children and

\footnotetext{
${ }^{25}$ The Category 1 case that was not censured was treated seriously by the judge, although it was a "lost cause" case. The youth had previous offending and was sentenced on the same day for other offenses.
} 
younger people, and to take responsibility for the future. They were less likely to provide norms of conduct to youths in Category 3 (see Table 2). ${ }^{26}$

Table 2. Judges’ norm-setting messages*

\begin{tabular}{|c|c|c|c|c|}
\hline Judges set norms about & $\begin{array}{l}\text { Category } 1 \\
N=32 \text { cases } \\
\% \quad(N)\end{array}$ & $\begin{array}{l}\text { Category } 2 \\
\mathrm{~N}=13 \text { cases } \\
\% \quad(\mathrm{~N}) \\
\end{array}$ & $\begin{array}{l}\text { Category } 3 \\
\mathrm{~N}=10 \text { cases } \\
\% \quad(\mathrm{~N})\end{array}$ & \begin{tabular}{c}
\multicolumn{2}{c}{ Total } \\
$\mathrm{N}=55$ cases \\
$\% \quad(\mathrm{~N})$
\end{tabular} \\
\hline $\begin{array}{l}\text { Appropriate male-female } \\
\text { sexual relations }\end{array}$ & $6 \% \quad(2)$ & $8 \% \quad(1)$ & none & $6 \% \quad(3)$ \\
\hline Respecting others & $34 \%(11)$ & $31 \% \quad(4)$ & $20 \% \quad(2)$ & $31 \%(17)$ \\
\hline $\begin{array}{l}\text { Protecting children and } \\
\text { younger people }\end{array}$ & $47 \%(15)$ & $15 \% \quad(2)$ & $10 \% \quad(1)$ & $33 \%(18)$ \\
\hline $\begin{array}{l}\text { Taking responsibility for } \\
\text { future behavior }\end{array}$ & $59 \%(19)$ & $39 \% \quad(5)$ & none & $44 \%(24)$ \\
\hline $\begin{array}{l}\text { Total: judges gave one or } \\
\text { more norm-setting } \\
\text { messages }\end{array}$ & $78 \%(25)$ & $69 \% \quad(9)$ & $30 \%$ & $67 \%(37)$ \\
\hline
\end{tabular}

*Table note:

1. Judges may give more than one norm-setting message to each youth.

\section{$\underline{\text { Respect others }}$}

In a third of cases (somewhat lower for Category 3), the judges emphasized that in their future social relationships, the youths must respect others and cause no harm; but in only three cases, did the judges discuss appropriate male-female sexual relations. Instead, they focused on social relationships, in general, not on gendered social relationships, as in this Category 2 case: "You have to remember that you have to treat people with much more consideration than imposing what you want upon them in any way.”

\footnotetext{
${ }^{26}$ Three cases were not censured or subject to norm-setting: the two "lost cause" cases, and an historical sexual abuse case and the offender was 27 when sentenced.
} 
In the three cases in which judges talked about male-female relations, their remarks were directed to a youth who had simulated sexual activity with a 6-year-old girl, one who had exposed himself to a shop assistant (an adult woman), and one who was 17 when he assaulted a 13-year-old girl. Toward the first, the judge said, "What I want you to do is ... see what you can do in the future ... to make it plain to those about you that young girls have nothing to fear from you, that young people have nothing to fear from you.” Toward the second, the judge said, “you know [that] you can't do that sort of and that it causes distress to women who are subjected to that sort of thing.” To the third, the judge said "I trust, Joseph, that in the future you will make it clear by your conduct that you respect girls, and that you take care to look after them when you are out with them....” This judge, who was nearing retirement, at times expressed more conservative views about youth and sexuality, although it was not typical. For example, later in the remarks to Joseph, the judge expressed strong reservations toward "sexual intercourse between unmarried people,” saying it was “a good way to get venereal disease ... The health point of view is important, but even more important is your approach to the moral question.”

The judge's comment to Joseph was atypical both for this judge and the four others. In their remarks, the judges did not reinforce traditional gender stereotypes nor paternalistic notions of respect. Nor did they suggest that a youth's coercive or violent actions constituted acceptable male behavior. At the same time, they did not explicitly challenge cultural or gender stereotypes that support sexual violence or the social attitudes that underpin male sexual aggression toward girls and women.

About one-third of Category 1 cases had male victims, all but one of whom were under 12. In the one case, which was proved of rape, both the male victim and offender 
were $16 \frac{1}{2}$ years old and school friends. The judge insisted that the offender, who had an intellectual disability, receive therapy at Mary Street. The offender’s disability may have affected the judge's decision, but it is important to recall that none of the youths who assaulted female peers was viewed as requiring the Mary Street program. Although the number of cases is small, male-male sexual assault among peers seemed to be greater judicial concern than male-female sexual assault among peers.

Protect children and younger people

When there was a large age gap (typically five years or more) between an offender and victim when the offense was committed, judges were more likely to say that youths should assume a protective role toward younger, more vulnerable people, and that they should act like role models and not abuse the trust placed in them. Expectedly, this normative message was more frequent in Category 1 cases because almost all the victims were under 12 . In a Category 1 case with a 5-year-old male victim, this is what the judge said to the male offender, who was 19 at the time of sentence:

You must remember that by reason of your age ... you are in a position where young children will follow directions, and do what you tell them without much query. You are so much older than they are. You therefore have a real responsibility to be very careful with young children and not to interfere with them, not to direct them to do anything which may be wrong or harmful, and to take double care of young children as compared with people of your own age and stature.

In all the cases with child victims, the sex of the child was somewhat irrelevant to the judge's norm-setting. The focus of the judicial address was on all children's 
vulnerability and need for protection, as the judge's advice to Lucas, who indecently assaulted a 5-year-old girl illustrates:

That is how seriously sexual abuse of children is regarded by the courts and by the community whom the court represents, and you have to realize that. It is regarded with horror, I suppose. Young children have an absolute right to be protected from all abuse. They cannot be sexually abused or molested.

Judges set individual norms of conduct to the youths, but they also used the remarks to reinforce societal norms and expectations that strongly prohibit sexual relations with children.

\section{Take responsibility for the future}

In addition to norm-setting, the judges told the youths what they needed to do in the future. They often said to Category 1 and 2 youths that they must take responsibility for their future behavior by addressing specific problems that, in the judges' minds, were contributing to their offending. For Category 1 youths, the judges insisted that they seek treatment for their aberrant sexual behavior, whereas for Category 2 youths, the judges emphasized therapy for mental health problems, which were often linked to a history of abuse and victimization, or to substance abuse. The judges were even more adamant that youths had to take responsibility for future behavior when they had already been offered help in the past (sometimes as the result of previous offending), but had not taken advantage of it. The judge’s final words to Richard (Category 1) exemplify this stance: "It is over to you, Richard. If you come back, you will only have yourself to blame for not taking up the help that has been offered.”

In other cases, judges conveyed a similar message of the youth’s need to “take responsibility,” although in somewhat less blunt terms. Tara, who is in Category 1 and 
the only female offender in the sample, had been sexually victimized. She had received some therapy, but was not responding. The judge acknowledged Tara’s own victimization, but said that it did not reduce her responsibility for past or future behavior:

Time and time again I tell young people that help can be offered, but it is not going to be successful unless you are prepared to accept it, and work with the people who are offering you that help. ... I am obliged to make sure that you realize that, not withstanding your background, you have to take responsibility for your behavior yourself.

Although the judges acknowledged that some youths’ offending may be linked to a history of victimization and abuse or other problems, they did not excuse the offenses; rather they emphasized to the offenders that they had a responsibility to address these problems.

To summarize, in most cases (except those in Category 3), the judges censured the offending as a moral wrong and a violation of victims, and they attempted to convey to the youths what were rightful norms of conduct. They explicitly challenged sexual relations with all children (male and female), although they did not challenge social attitudes supporting male aggression toward female peers. Next, we consider the ways in which judges communicated the message; that is, did they engage in a moral dialogue with offenders, or did they lecture them? 


\section{How did judges communicate?}

Judges addressed the offenders directly, but rarely interacted with them actively. More often, the sentencing homily was a one-way solo performance that blended moral lecturing with threats of further legal liabilities.

\section{Moral dialogue or moralizing?}

Judges spoke to the young people, but rarely with them. Typically, they discussed the moral and practical consequences of sex offending, and exhorted offenders to change their ways, but this largely took the form of a moral lecture, not the thought-provoking moral dialogue recommended by Weijers (2002, 2004). For Category 1 youths, who were referred to Mary Street, a recurring element in the judicial address was that a youth would have the opportunity to talk about and confront his sexual behavior with a Mary Street therapist in a place that would be more conducive for such discussion than the courtroom.

Judges asked questions of the youths in $42 \%$ of cases, but these were of a rhetorical nature and were rarely meant to engage the adolescents. ${ }^{27}$ In just six cases, a real dialogue took place between the judge and defendant. ${ }^{28}$ The following excerpt illustrates how the judge challenged Malcolm (Category 2) about his drug taking. The judge persevered even though Malcolm’s response was perhaps not what was expected:

Judge: Well, do you think that you would have done it sober? Do you think you would do it now?

Malcolm: No, I don't, not at all.

\footnotetext{
${ }^{27}$ Judges typically enquired whether the youths understood what was required of them, and the youths always answered they did; or judges asked if the youths wished to say anything, and the youths always answered they did not.

${ }^{28}$ All were sentenced by the same judge; however, this judge did not always engage in a moral dialogue. The six youths with whom the judge did engage in a dialogue were in Categories 1 and 2; they had a history of previous offending as well as personal problems.
} 
Judge: No. Do you see a link between getting drunk and getting off your face on marijuana, and committing crime? Do you see any link between that? Do you think one thing might affect the other?

Malcolm: Not really. I've smoked more marijuana than I do crime. Do you know what I mean?

Judge: Well, I do. That's just as well. We wouldn’t want you committing crime every time you smoked marijuana, would we?

Malcolm: No.

Judge: Do you think that you might perhaps commit no crime if you didn't lose your head?

Malcolm: I could sort of try, I suppose.

Judge: I think that's right...

By prompting the youth to reflect about the consequences of his drug taking, the judge encouraged him to accept responsibility for his future behavior. Eliciting self-reflection is one of the aims of the moral dialogue. Weijers (2002) suggests that the moral dialogue should also help offenders identify the moral consequences of the offense, and particularly the harm caused to the victims, their families, and to those close to the offenders. This did not feature in any of the six cases that had some dialogue. Rather, when the judge engaged in a discussion with offenders, it was typically to persuade them to change their lifestyle. In the following exchange, the judge asked Trevor (Category 1), who was nearly 16 at the time of sentencing, about his therapy and his life in a hostel:

Judge: How are you finding the sessions with [Mary Street therapist]?

Trevor: I don’t like the idea of going once a week. 
Judge: Why is that?

Trevor: Because I like to have a week where I can think about my own things and have a week doing my own things and then the second week, then I can go to counseling and be able to discuss it and like, sometimes I come home a bit down and angry and stuff because of how wrong it was, but it is going all right.

Judge: But, don't you realize that it's a helpful process?

Trevor: Yes, it is, it's helped me heaps.

Judge: In fact you must realize that it's essential surely. ... What about what I've heard this morning about recent drug taking?

Trevor: I just basically mixed with the wrong crowd, and got stuck into stuff just to be in the group.

Judge: Yes.

Trevor: But I'm getting away from all them now and starting to put my mind to other things, more important stuff.

Judge: Such as?

Trevor: Um, independent living, learning to cook and stuff. I am doing my "Ls",29 now, computer tests and stuff and things like that. Stuff I can spend my money on instead of drugs.

During this exchange, the judge attempted to reinforce to the youth what he should do: engage in the Mary Street program and stay away from drugs. Such dialogues were infrequent. Judges more often lectured the offenders and typically used threats and warnings.

\footnotetext{
${ }^{29}$ This refers to the L-plates that are placed on the car of people learning how to drive in Australia. The L-plates symbolize learning drivers and by extension, anyone learning new skills.
} 


\section{Threats and warnings}

Threats of further legal liabilities, with associated warnings of more severe treatment in the event of re-offending, were made in $78 \%$ of cases. Such threats were made across the three categories, although a bit less often to Category 3 youths, who were seen as less likely to re-offend. ${ }^{30}$ Neither the young people’s previous criminal history, nor the judges' perception of the likelihood of future offending was associated with threats of further legal liabilities. Rather, such threats and warnings were part of the judges' standard message. As we would expect, threats and warnings occurred in all the cases when suspended detention was imposed, but they were not reserved for these cases. For instance, in a Category 1 case where a good behavior order and counseling were imposed, the judge said, "If you were an adult, these matters could easily result in you serving a term of prison.” Then, the judge added, "I am on this occasion going to be reasonably lenient, but you should realize that this is your first and last chance to get such leniency.” To the young people in court, the message is clear: leniency may be afforded in the Youth Court, but if the youth returned to the court, the penalties would become more severe.

Degradation vs. reintegration ceremonies?

Contrary to Braithwaite and Mugford's (1994) assumption of youth court processes as degradation ceremonies, and like Kupchik (2004), we find that the judicial address was not exclusionary, but went some way toward reintegration. Judges censured the deed in almost all cases, but they were critical of the offender, as a person, in only eight cases (15\%). For example, the judge said to Wayne (Category 1):

\footnotetext{
${ }^{30}$ Threats of further legal liabilities were given in $88 \%$ of Category 1 cases, $69 \%$ of Category 2 cases, and $60 \%$ of Category 3 cases.
} 
There has been a period for some little time where you have just turned yourself into a rebel, haven't wanted to take any notice of what your mother or your father have to say about things. In simple terms, there are all the indications that in the last twelve months ... you have been getting a bit too big for your boots.

Category 2 youths were half of those who were criticized as people, and we suspect this was because all had a history of offending.

In two-thirds of cases, judges conferred praise and encouragement on the youths. This could be for their achievement at school or in sports, a more mature attitude since the offense, or the efforts they were making to come to terms with their offending. In all cases, judges talked to the young persons with respect. They did not reject offenders, but showed confidence in the youths' ability to stop their sexual offending and become "good and useful members of the community." The judge's address to Alex (13 years old, Category 1 ) is typical of the way in which judges expressed to the youths that they have a non-offending future ahead of them:

In other words, but for the series of incidents, which have brought you here today, you have the usual hope and aspirations of boys of your age.... You are well on the way to showing that you are truly sorry. You can show that by making sure it never happens again. You can show that by making sure that the life that you lead, the life ahead of you, is a good and useful one, a happy life, and one of which you can be proud.

As the excerpt below shows, judges endeavored to build a non-deviant identity for the adolescents by reinforcing they have the ability to change:

Roy, I accept everything that is in the reports and that your lawyer has told me this morning but, of course, what you have got to realize and I am sure you are realizing 
it, is that what you did to your sister was very wrong and very serious and something which the law and the community take a very serious view about. You have seen what happened to your father and where he is now ... but, of course, you are in a very different position than your father. You suffered at his hands. ... However, you are getting help with it. You realize it was wrong and you want to get on with things and put it behind you, and I am going to give you that chance. I am sure there won't be any repetition of this ... (Category 1).

In Roy's case, the judge wanted to distinguish him from his father, who was incarcerated for sexually abusing children, including Roy. The judge emphasized that Roy was different from his father because he realized that what he did was wrong, and thus, he could change.

\section{DISCUSSION}

The judicial orientation to youth sex offending varied by elements of the offense (specifically, by the age of victims and the offender-victim age gap) and a youth's criminal history. Judges had heightened concerns when sentencing youths who sexually offended against those under 12 (Category 1 ) or who appeared to have a criminogenic lifestyle (Category 2), compared to those who were seen as sexual experimenters (Category 3). Although the judges censured offenses as moral or legal wrongs, or both, and they attempted to provide norms of conduct to guide the youths' future relationships, the strength of the censure and norm clarification varied by the three-way typology. Specifically, Category 3 youths were viewed as having done something wrong only in a legal sense; their past behavior was subject to a pseudo censure, and their future behavior was not a cause for judicial concern or advice giving. 
Although judicial censure formed part of the sentencing address, the judges spent more time discussing the youths’ future than past behavior. Like Kupchik (2004) and Vignaendra and Hazlitt (2005), we found that the judges wanted to help the youths address and overcome problems, which they perceived as having a role in the youths' offending. Echoing Emerson’s (1969: 188) observations that the court places responsibility for change on offenders, the judges in our study emphasized that it was up to the youths to accept the help that was offered and to cooperate with therapists and youth workers in changing their circumstances and lifestyle. With just two youths receiving detention time to serve, situational sanctions (Mileski, 1971) and admonishments (Kupchik, 2004), often in the form of threats of future legal liability if the young person broke the law again, were typical. Threats and warnings against future offending are common elements in youth court interactions and have been documented by others (e.g., Emerson, 1969; O’Connor \& Sweetapple, 1988; Tait, 2002; Vignaendra \& Hazlitt, 2005).

With some attention on the past offense, but with greater attention on the future, the judges did not limit themselves to censuring the past wrong in the manner suggested by von Hirsch (1993). By highlighting the impact of the offending on victims and the potentially negative consequences for the offenders, judges tried to persuade the offenders to reform and change their outlook and future behavior. This aspect of the judicial discourse is consistent with Duff's (1996, 2002) and Weijers' (2002) proposition that censure and moral education in court should lead offenders to reflect upon and alter their behavior. A small share of cases (11\%) evinced Weijers' (2002, 2004) pedagogical approach to moral communication with some elements of youthjudge interaction. More typically, the moral communication was monologic. Rather 
than eliciting self-reflection, the judicial remarks were advice giving and lecturing, with little moral probing.

Judges also provided norms of conduct to most youths. They reinforced societal norms that strongly condemn the sexual abuse and exploitation of all children, regardless of their sex. This is consistent with MacMartin and Wood's (2005) finding that judges strongly censure the sexual abuse of children by adults. By contrast, the judges did not propose norms of conduct in heterosexual relations for those of a similar age. Although they emphasized the importance of respecting the rights of others in general, they did not speak of how such respect (or sexual autonomy) should be evinced in heterosexual peer relations. As Warner $(2004,2005)$ points out, this would require confronting the cultural and social attitudes that support male sexual aggression toward females. The judges displayed greater comfort in using their remarks to bolster societal norms of protecting children from sexual abuse, than to re-educate youth on appropriate male-female sexual relations.

\section{Implications for offenders and victims}

Most offenders were reprimanded for their action, but across the three categories and regardless of the seriousness of offending, it was uncommon for the youths to be criticized as persons, and there were no examples of humiliation or degradation such as Garfinkel (1956) described. Even in the most serious cases of sexual offending against young children, the youths were addressed by the judges as worthy individuals who were capable of change and in ways that did not exclude them further. The judges encouraged the youths to use their talent and potential positively and toward a future crime-free life. Unlike the judges in Emerson's (1969) study who tended to discredit 
the youths' character, the judges in our study attempted to strengthen a non-deviant identity. Although Braithwaite and Mugford (1994) argue that restorative justice conferences are more conducive to the reintegration of offenders than court hearings, our study finds that these South Australian judges did not exclude and stigmatize offenders, but gave them a chance to reform. The court process showed many elements of reintegration. ${ }^{31}$ On balance, the judges related to the youths in a manner that suggests high levels of procedural justice (e.g., being treated fairly and with respect). Tyler (1990) argues that this judicial orientation can, in turn, have a positive impact on strengthening a defendant's belief in and respect for legal authority.

Victims and their families would likely have felt vindicated by the judges' remarks in about two-thirds of cases, broadly all of Category 1 cases and a portion of those in Category 2. By censuring the offense as both a moral and legal wrong, judges confirmed to these victims that their suffering was caused by someone else who violated them. However, some of these victims or members of their families may have thought that the sentences imposed were too lenient, or that the ways in which judges addressed the offenders were too kind. The victims of the youths who were referred to Mary Street may have some solace in knowing that these youths will be expected to reflect on the harm they caused and to change their outlook. Recall that ten intra-familial cases involved siblings as victims and offenders. The parent(s) in these cases typically take a support role for both the victim and offender; with allegiances to both parties, their views would be more complex and perhaps ambivalent.

\footnotetext{
${ }^{31}$ Since 1994, the response to youth crime in South Australia is by formal caution, diversionary (restorative justice) conference, or court. The judges work in the same building as the Family Conference Team members, who coordinate the conferences; they are familiar with and supportive of restorative justice conferencing.
} 
The victims in Category 3 cases would not have been vindicated by the sentencing remarks because the offenses were interpreted by the judges as consensual underage sex or subject only to a "pseudo censure,” when most victims had reported coerced sex to the police. The message to Category 3 offenders is that their behavior was not "really" wrong, something the victims would have disputed. This judicial response is similar to that for adult sexual assault between those known to each other (e.g., acquaintance or partner rape), which is often not treated by the legal process as coercive sex. Censuring such offenses and vindicating victims appears to be as difficult to accomplish in the youth court as the adult court.

\section{Implications for court practices}

In adult criminal courts, a judge’s sentencing homily, although directed to a defendant, can have a wider potential audience. The sentencing remarks are not only given in an open courtroom, with general members of the public and the press present, but also they are published on websites in many jurisdictions. In sentencing adults convicted of sex offenses, Warner (2005: 248) suggests that judges “could be encouraged to adopt an educative role” in using the remarks to challenge dominant rape myths and community attitudes or stereotypes about sexuality: specifically, that stranger rape is "real rape” and acquaintance, partner, or marital rape are not; and that when victims act in "provocative” way, offenders are unable to "control their sexual urges once aroused" (pp. 244-45).

In youth courts, the character of sex offending differs from that in adult courts. Specifically, in the court we studied, the majority of the most legally serious cases involved victims under 12 years of age. All of these cases (nearly $60 \%$ of the sample) 
were treated as serious, and as "real rape," although they involved known relations (siblings, other family members, or close acquaintances), one-third had male victims, and one-third did not involve sexual penetration. The judicial norm clarification centered on the wrongs of sexually abusing or exploiting children, not on gender and sexuality. Rather than discussing in the courtroom what are appropriate sexual relations, the judges shifted this task to the Mary Street program counselors. People may disagree about whether judges ought to say more in these cases. At a minimum, we might expect their remarks to align with the broad aims of a therapeutic intervention.

The judicial reaction to cases in which victims were 12 years or older varied by the context of the offense, the age difference between offender and victim, and whether non-sexual offenses were sentenced at the time as the sexual offense. A portion of these cases (that is, ten Category 3 cases, or 18\% of the sample) were not treated seriously. What should judges do in these cases? At a minimum, we might expect that they should censure the offense as a moral wrong. In addition, some may argue that judges should adopt the educative role proposed by Warner: to use the sentencing hearing to challenge and impugn rape myths, and to depict more appropriate, “equal sharing relationships” (Warner, 2005: 247 citing Ashworth, 2003). Such a role may not come easily to judges, and they may resist it as being inappropriate. ${ }^{32}$ It is also possible that some judges would undertake an educative role in ways not condoned or anticipated by feminist or victim advocates. Even if judges did use the sentence hearing to challenge rape myths, we would be naive to think their words would necessarily affect a youthful defendant, who may be only selectively "hearing” or understanding what the judge is

\footnotetext{
${ }^{32}$ Two judicial officers in responding to this educative role had different reactions. One believed that the courtroom context was inappropriate to determine and analyze an offender's beliefs, which in any event, were better left to the expertise of counsellors; and another said that judicial officers were not trained in this educative role and would require training.
} 
saying. Indeed, the judge's words may have as much or greater significance for others in the courtroom.

\section{REFERENCES}

Anderson, V., Simpson-Taylor, D., \& Herrmann, D. (2004) Gender, age, and rapesupportive rules. Sex Roles, 50, 77-90.

Ashworth, A. (2003) Principles of Criminal Law (4 ${ }^{\text {th }}$ ed.). Oxford: Oxford University Press.

Berg, B. (2004) Qualitative Research Methods for the Social Sciences. Boston: Pearson.

Bouhours, B. \& Daly, K. (2007) Youth sex offenders in court: an analysis of judicial sentencing remarks. Punishment and Society, 9(4), 371-94.

Braithwaite, J. (1989) Crime, Shame and Reintegration. Cambridge: Cambridge University Press.

Braithwaite, J. \& Mugford, S. (1994) Conditions of successful reintegration ceremonies. British Journal of Criminology, 34, 139-71.

Christie, N. (1977) Conflicts as property. British Journal of Criminology, 17(1), 1-15.

Coates, L., Bavelas, J., \& Gibson, J. (1994) Anomalous language in sexual assault trial judgments. Discourse and Society, 5, 189-206.

Coates, L. \& Wade, A. (2004) Telling it like it isn’t: obscuring perpetrator responsibility for violent crime. Discourse and Society, 15, 499-526.

Daly, K. (1994) Gender, Crime, and Punishment. New Haven: Yale University Press. 
Daly, K. (2006) Restorative justice and sexual assault: an archival study of court and conference cases. British Journal of Criminology, 46, 334-56.

Daly, K., Bouhours, B., Curtis-Fawley, S., Weber, S., \& Scholl, R. (2005) South Australia Juvenile Justice and Criminal Justice (SAJJ-CJ) Technical Report No. 3: Sexual Assault Archival Study (SASS), An Archival Study of Sexual Offence Cases Disposed of in Youth Court and by Conference and Formal Caution ( $2^{\text {nd }}$ ed.). Brisbane: School of Criminology and Criminal Justice, Griffith University. Available at http://www.griffith.edu.au/school/ccj/kdaly.html

Daly, K. \& Curtis-Fawley, S. (2006) Restorative justice for victims of sexual assault. In K. Heimer \& C. Kruttschnitt (eds.), Gender and Crime: Patterns of Victimization and Offending (pp. 230-65). New York: New York University Press.

Duff, A. (1996) Penal communications: recent work in the philosophy of punishment. In M. Tonry (ed.), Crime and Justice: A Review of Research, Vol. 20 (pp. 1-97). Chicago: The University of Chicago Press.

Duff, A. (2001) Punishment, Communication and Community. New York: Oxford University Press.

Duff, A. (2002) Punishing the young. In I. Weijers \& A. Duff (eds.), Punishing Juveniles: Principle and Critique (pp. 115-34). Portland: Hart.

Emerson, R. (1969) Judging Delinquents: Context and Process in Juvenile Court. New York: Aldine Publishing Company.

Epps, K., Haworth, R., \& Swaffer, T. (1993) Attitudes toward women and rape among male adolescents convicted of sexual versus nonsexual crimes. The Journal of Psychology, 127(5), 501-07. 
Friedman, B. (1998) Rape Myth-Busters: A Program for Young Men about Rape Prevention. Adelaide: SHine SA, South Australian Health Commission.

Garfinkel, H. (1956) Conditions of successful degradations ceremonies. The American Journal of Sociology, 61, 420-24.

Heumann, M. (1977) Plea Bargaining. Chicago: University of Chicago Press.

Hudson, B. (2002) Restorative justice and gendered violence: diversion or effective justice? British Journal of Criminology, 42, 616-34.

Kupchik, A. (2003) Prosecuting adolescents in criminal courts: criminal or juvenile justice? Social Problems, 50(3), 439-60.

Kupchik, A. (2004) Youthfulness, responsibility and punishment. Punishment and Society, 6, 149-73.

Kupchik. A. (2006) Judging Juveniles: Prosecuting Adolescents in Adult and Juvenile Courts. New York: New York University Press.

MacMartin, C. \& Wood, L. (2005) Sexual motives and sentencing: judicial discourse in cases of child sexual abuse. Journal of Language and Social Psychology, 24, 13959.

Mileski, M. (1971) Courtroom encounters: an observational study of a lower criminal court. Law and Society Review, 5, 473-538.

Murnen, S., Wright, C., \& Kaluzny, G. (2002) If “boys will be boys,” then girls will be victims? A meta-analytic review of the research that relates masculine ideology to sexual aggression. Sex Roles, 46, 359-75.

O’Connor, I. \& Sweetapple, P. (1988) Children in Justice. Melbourne: Longman Cheshire. 
Tait, D. (2002) Sentencing as performance: restoring drama to the courtroom. In C. Tata \& N. Hutton (eds.), Sentencing and Society: International Perspectives (pp. 469-80). Aldershot: Ashgate.

Taylor, G. (2002) Guilt, shame and shaming. In I. Weijers \& A. Duff (eds.), Punishing Juveniles: Principle and Critique (pp. 179-92. Portland: Hart.

Travers, M. (2007) Sentencing in the children’s court: an ethnographic perspective. Youth Justice, 7(1), 21-35.

Tyler, T. (1990) Why People Obey the Law. New Haven: Yale University Press.

Vignaendra, S. \& Hazlitt, G. (2005) The Nexus between Sentencing and Rehabilitation in the Children's Court of NSW. Sydney: Judicial Commission of New South Wales.

von Hirsch, A. (1993) Censure and Sanctions. Oxford: Oxford University Press.

Warner, K. (2002) Sentencing sexual offenders in the UK and Australia. In C. Tata \& N. Hutton (eds.), Sentencing and Society: International Perspectives (pp. 504-27). Aldershot: Ashgate.

Warner, K. (2005) Sexual offending: victim, gender and sentencing dilemmas. In D. Chappell \& P. Wilson (eds.), Issues in Australian Crime and Criminal Justice (pp. 233-51). Chatswood: LexisNexis Butterworths.

Weijers, I. (2002) The moral dialogue: a pedagogical perspective on juvenile justice. In I. Weijers \& A. Duff (eds.), Punishing Juveniles: Principle and Critique (pp. 13554). Portland: Hart.

Weijers, I. (2004) Requirements for communication in the courtroom: a comparative perspective on the youth court in England/Wales and the Netherlands. Youth Justice, 4(1), 22-31. 
White, B. \& Kurpius, S. (1999) Attitudes toward rape victims: effects of gender and professional status. Journal of Interpersonal Violence, 14(9), 989-95.

Xenos, S. \& Smith, D. (2001) Perceptions of rape and sexual assault among Australian adolescents and young adults. Journal of Interpersonal Violence, 16, 1103-19. 